\title{
[1]
}

\section{SOCIOLOGICAL RATIONAL CHOICE THEORY}

\author{
Michael Hechter \\ Department of Sociology, University of Arizona, Tucson, Arizona 85721; \\ e-mail: hechter@u.arizona.edu
}

\section{Satoshi Kanazawa}

Department of Sociology, Uris Hall, Cornell University, Ithaca, New York 14853-7601; e-mail: Satoshi.Kanazawa@cornell.edu

KEY WORDS: macrosociology, micro-macro link, general theory, empirical research

\begin{abstract}
Although rational choice theory has made considerable advances in other social sciences, its progress in sociology has been limited. Some sociologists' reservations about rational choice arise from a misunderstanding of the theory. The first part of this essay therefore introduces rational choice as a general theoretical perspective, or family of theories, which explains social outcomes by constructing models of individual action and social context. "Thin" models of individual action are mute about actors' motivations, while "thick" models specify them ex ante. Other sociologists' reservations, however, stem from doubts about the empirical adequacy of rational choice explanations. To this end, the bulk of the essay reviews a sample of recent studies that provide empirical support for particular rational choice explanations in a broad spectrum of substantive areas in sociology. Particular attention is paid to studies on the family, gender, and religion, for these subareas often are considered least amenable to understanding in terms of rational choice logic.
\end{abstract}

\section{INTRODUCTION}

In the last decade rational choice theory has gained influence and visibility in many of the social sciences and in related disciplines such as philosophy and law. To appreciate just how rapidly its influence has spread, consider political 
science, a discipline in many respects similar to sociology. According to one estimate, the proportion of articles based on rational choice premises published in the American Political Science Review rose from zero in 1957 to nearly $40 \%$ in 1992 (Green \& Shapiro 1994, p. 3). Job candidates specializing in rational choice now command a hefty premium in American political science departments.

Given its own disciplinary history, which is often characterized in relentlessly holistic terms, sociology would appear to be a most unpromising terrain for the spread of rational choice ideas and methods. Indeed, resistance to the approach has been notable (Baron \& Hannan 1994, Petersen 1994). No American sociology department currently specializes in rational choice; only one even offers its graduate students a concentration in it. No jobs are listed for specialists in the area. This is in contrast to the situation in Western Europe, particularly in the Netherlands, Germany, and Sweden, where rational choice is considerably more institutionalized.

Yet many sociologists, like the character in Moliére's Bourgeois Gentilhomme who was startled to learn that he was speaking prose, unwittingly rely on rational choice mechanisms in their own research. Signs of the growing acceptance of sociological versions of rational choice can be found in the establishment of the journal Rationality and Society, and in the regular proceedings of lively sections devoted to the approach in both the American and the International Sociological Associations meetings.

Some of the skepticism about rational choice among sociologists arises from misunderstanding. One criticism of rational choice focuses on the lack of realism in its assumption that we calculate the expected consequences of our options and choose the best of them. A vast body of social research reveals that people often act impulsively, emotionally, or merely by force of habit. Think how agonizing decisions about jobs, spouses, and children can be. Were people the informed and calculating agents that rational choice theorists assume them to be, such decisions would not be particularly wrenching. Since these choices often take an emotional toll, it is easy to conclude that the theory is implausible.

This conclusion, however, rests on a common misconception about the nature of rational choice. The theory does not aim to explain what a rational person will do in a particular situation. That question lies firmly in the domain of decision theory. Genuine rational choice theories, by contrast, are concerned exclusively with social rather than individual outcomes. Given that each individual acts rationally, will the aggregate outcome therefore be "rational" or desirable? Not necessarily. Regarded as stable equilibria, in which agents have no incentive to deviate from their course of action, given others' behavior, social outcomes can be both unintended and undesirable. The overgrazing of the commons is a classic example of this dark side of Adam Smith's invisible hand. 


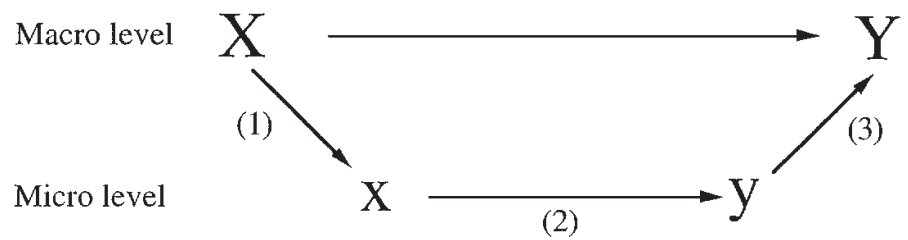

Figure 1 The multilevel structure of rational choice explanations (after Coleman 1990, p. 8).

Unlike decision theory, rational choice theory is inherently a multilevel enterprise (Figure 1). At the lower level, its models contain assumptions about individual cognitive capacities and values, among other things. Relation (2), for example, describes how a person who is subject to a given social structure at $\mathrm{T}_{1}$ will behave at $\mathrm{T}_{2}$ on the basis of these assumptions. Whereas relation (2) is necessary, it is far from the whole story. At the higher level, rational choice models also contain specifications of social structures. These social structures serve both as the social and material context $(\mathrm{X})$ for individual action, and as new structures $(\mathrm{Y})$ resulting from the actions of individuals whose behavior is described by the lower level assumptions (Coleman 1990, pp. 1-23). Since norms and other kinds of institutions enter the models both as contexts for and as outcomes of action, rational choice theories do not rest on premises pertaining exclusively to individuals.

A second criticism of rational choice focuses on its motivational assumptions. Rational choice theorists regard both individual values and structural elements as equally important determinants of outcomes, but for methodological reasons their empirical applications typically place greater emphasis on social structural determinants. In consequence, rational choice explanations often are consistent with those of other general perspectives, such as structuralism and network analysis, that are usually regarded as lying well within the sociological mainstream (Goldthorpe 1996). One source of this methodological predilection lies in concerns about measurement. Values and other internal states are far more difficult to measure than structural constraints, which are external to individuals (Hechter 1992). Measuring values from the verbal responses to direct survey questions is problematic (Fischhoff 1991). Some progress in measuring values is being made, however. For example, matching models (Logan 1996a) offer one means of measuring individual values indirectly without relying on peoples' responses to questions about their own internal states.

The treatment of values in rational choice theory is due not only to methodological considerations; it is also a reaction to the complexity that is inherent in the multilevel nature of the theory. To reduce this complexity to more manageable limits, rational choice theorists assume some model of individual action, 
often one based on subjective-expected utility theory. They disagree about the most appropriate model, however. And so rational choice is more a rubric or a family of theories than a single all-encompassing one.

Perhaps the most important division separates "thin" and "thick" models of individual action (Ferejohn 1991; for a fuller discussion of the differences between rational choice theories, see Goldthorpe's unpublished paper "Rational Action Theory for Sociology"). Thin rational choice models are unconcerned with the particular values (or goals) which individuals pursue. These models are based on a small number of strong assumptions: for example, that whatever an individual's values may be, they must be stable and transitive (if someone prefers $a$ to $b$, and $b$ to $c$, they must prefer a to $c$ ). Rational choice theories based on thin models - such as those usually found in economics and social choice theory - are highly universalistic and to that extent resemble theories in physics and biology concerning the optimal behavior of atoms and organisms.

Thick models of individual action, advocated long ago by Max Weber, are substantively richer, for they countenance some aspects of intentionality. Since people have reasons for what they do, their behavior is predictable only if we know what motivates them. Thick models therefore specify the individual's existing values and beliefs. There are several means of doing so, but the most popular strategy has been to assume that individuals seek maximum quantities of exchangeable private goods such as wealth and, arguably, power or prestige. Wealth is commonly valued because it can be exchanged for a multitude of other goods in the marketplace. Thick models allow that individuals also value nonexchangeable goods - that some people live for the music of Mozart, and others for the thrill of horse racing. Indeed, the models assume that for any given individual, idiosyncratic values of this sort can outweigh the common one. Hence, without knowing each person's unique value hierarchy, individual behavior is unpredictable. As the size of groups increases, however, these idiosyncratic values tend to cancel each other out. In many circumstances the remaining common value permits quite accurate behavioral predictions at the collective level (Hechter 1994). Some rational choice theories specify other common values that individuals pursue, such as uncertainty reduction (Friedman, Hechter \& Kanazawa 1994), local status (Frank 1985), and distributive justice (Jasso 1990, 1993). Other rational choice theories are beginning to model the processes that might be responsible for the formation of these common values (Becker 1996, Chai forthcoming).

Contrary to some perceptions (England \& Kilbourne 1990, pp. 160-61), thick rational choice theories do not necessarily assume that individuals are selfish agents. These theories can postulate any individual values at all, not excluding complete altruism. What is required is merely that individuals are self-interested, not selfish (Friedman \& Diem 1990). 
Thin models are substantively empty. They can be made consistent after the event, therefore, with nearly any kind of behavior. Thick ones - such as those postulating wealth-maximization - often are just plain wrong. To the degree that the idiosyncratic values are not distributed randomly in a population, explanations based on the pursuit of exchangeable private goods such as wealth, power, and prestige will fail. Since outcomes may be partially a function of individual motivations, predictions made on the basis of thick models can be mutually inconsistent. Such inconsistencies can only be resolved on the basis of empirical evidence. That decision theorists can routinely invalidate subjective expected utility theory is also troubling, even if they have yet to formulate an alternative superior to it. All told, the mechanisms of individual action in rational choice theory are descriptively problematic. Is a theory of higherlevel outcomes invalidated by the inaccuracy of its lower-level mechanisms? Rational-choice theorists deny that it is (see Hechter 1996).

Not all sociological reservations about rational choice derive from misunderstanding, however. Above all, rational choice is a theory-driven enterprise: Many authors seem to value formal proofs of theories more than the confirmation of these theories on the basis of rigorous empirical tests. Advocates often argue on its behalf, with not a little hauteur, by asserting that rational choice is the best available general theory in the social sciences. Since theories ultimately are judged by their capacity to account for empirical observations, the criticism (levelled by Green \& Shapiro 1994, among others) that many rational choice theories are either false or remain untested cuts close to the bone.

The appeal of rational choice in sociology is unlikely to increase substantially until the approach provides demonstrable empirical payoffs in a wide variety of substantive areas. In what follows, we review a sample of empirical applications of rational choice in sociology published in English since 1988, when the last survey of the contributions of rational choice to macrosociology appeared (Friedman \& Hechter 1988, pp. 204-11). Whereas most of these are explicitly derived from rational choice premises, we also discuss several theoretically unmotivated studies that report findings consistent with rational choice. Inclusion of this latter category of studies may be questioned. After all, if such studies can be carried out without reference to rational choice, then why is the theory necessary? One answer is that rational choice provides a heuristic framework that permits the diverse findings in all of these fields to be unified. Another is that it aids in making the logical links between different theories more explicit. Finally, readers should be aware that this essay is not a survey of sociological rational choice in its entirety, for it ignores the purely theoretical developments that continue to make up the bulk of research in this field (Coleman 1990 is the most important of these). 


\section{RECENT EMPIRICAL APPLICATIONS OF SOCIOLOGICAL RATIONAL CHOICE}

Many critics readily concede that rational choice may be appropriate for the analysis of voluntary exchanges in the Gesellschaft, which constitutes the traditional terrain of economics. However, they contend that it can shed little or no light on social relations in the Gemeinschaft-those involving the family, religion, and gender. For this reason, we begin our review with recent applications in these areas.

\section{The Family and Demography}

The family was once thought to fall outside the purview of rational choice (Sen 1983) because this primordial institution (Coleman 1993) engenders hot motivations - love and hate - rather than cold benefit/cost calculations. In a number of influential writings, Becker $(1974,1981)$ questioned the wisdom of dividing social relations into separate domains, each requiring its own distinctive analysis (Abell 1991). Following his lead, rational choice now is routinely applied to individuals' family decisions.

Two recent programmatic statements in this subarea resonate strongly with rational choice. The concept of "family adaptive strategies" (Moen \& Wethington 1992) captures the notion of choice under constraints (with the family as the unit of decision-making) in life course studies in sociology. Likewise, Smith (1989) calls for a multilevel analysis of fertility. Many of the findings in the empirical literature are entirely consistent with rational choice theories. For example, Lloyd \& South (1996) show that, net of individual characteristics, men's transition to first marriage is strongly influenced by the structural constraints they face, in the form of the availability of prospective partners in the local marriage market. South \& Lloyd (1995) demonstrate that the aggregate divorce rates fluctuate with the structural opportunities available to spouses; the quantity and quality of potential new marital partners in the local marriage market significantly increase the risk of marital dissolution. This substantiates Becker's (1974, pp. S21-S23) suspicion that men and women continue to search for mates even while they are married. Together, these studies indicate that marriage and divorce are subject to the same external opportunities and constraints as exchanges in the market.

Other research exemplifying how structural factors shape individual behavior and social outcomes (relations 1 and 2 in Figure 1) includes Brewster's (1994, Brewster et al 1993) study of community effects on adolescent sexual activities; Lee et al's (1994) analysis of the neighborhood effects on residential mobility; Hoem's (1991) demonstration of the impact of legal changes on marriage rates in Sweden; and Hoem's (1993) findings concerning the effects of legal incentives on childbearing. 
In contrast to marriage and divorce, standard microeconomic explanations of parenthood in the postindustrial age have not fared so well empirically. Prior to industrialization and the implementation and enforcement of child labor laws, having children made ample economic sense to parents. But why do individuals in the postindustrial age continue to have children when their net economic benefit for doing so is negative? Friedman et al (1994) propose a theory of uncertainty reduction to account for parenthood in advanced industrial societies. They argue that children in the postindustrial age serve as a means to reduce uncertainty for women and couples, and they predict that those who face greater uncertainty in their lives and/or lack alternative means to reduce uncertainty are more likely to become parents. This theory has been largely supported in its first empirical test (Wu 1996).

Once people decide to have children, when do they stop? Yamaguchi \& Ferguson (1995) explain rates of stopping and spacing childbearing by assuming that parents derive higher value from having children of both sexes than from having those of a single sex. Thus they predict that parents with two boys or two girls are more likely to have a third child than are parents of a boy and a girl, and the conclusions of their analysis of census data are consistent with this prediction.

In addition to its contributions to the study of fertility, rational choice has also been applied to migration. Jasso \& Rosenzweig (1990) study immigration to the United States as a matching process. On the one hand, potential immigrants must decide to emigrate from their countries of origin and choose a country of destination. On the other, host countries evaluate potential immigrants on a set of criteria and decide whom to welcome (Jasso 1988). Successful legal immigration takes place only when there is a match between the self-selective immigration decisions of foreign-born persons and the eligibility-conferring decisions of the host nations (Jasso \& Rosenzweig 1990, p. 7). Immigration therefore is a process of matching between two sets of actors, each attempting to achieve goals and operating under constraints created by the other.

Because migration should entail some loss of social capital (Coleman 1990), parental support ought to be crucial for the life prospects of children subsequent to family migration. Hagan et al (1996) analyze the mobility histories of Toronto families and find support for Coleman's expectation that the negative effects of migration are more significant in families with uninvolved fathers and unsupportive mothers. (See Farkas 1996 for a comprehensive study of the effects of social and cultural capital on individuals' achievements.)

\section{Religion}

Religion is another subject once deemed unpromising for rational choice analysis. This has not prevented the development of a lively rational choice literature about it, however (Stark et al 1996; Warner 1993 is a comprehensive review). 
The rational choice approach to religion draws a close analogy between religion and the market economy (Stark \& Bainbridge 1985, 1987, Young 1997). It conceives of a religious economy consisting of religious firms and religious consumers. Religious firms compete against one another to offer religious products and services to consumers, who choose between the firms. Stark \& Bainbridge (1987) extend this analogy and offer a large number of propositions concerning the religious economy.

They argue, for example, that the more pluralistic a religious economy is, the higher the level of religious mobilization. To the extent that there are many religious firms competing against each other, they will tend to specialize and cater to the particular needs of some segments of religious consumers. This specialization and catering in turn increase the number of religious consumers actively engaged in the religious economy. This proposition has been confirmed in a number of empirical studies. A positive correlation between pluralism and religious mobilization and commitment has been found in 17 Western nations (Iannaccone 1991), in 45 Catholic nations (finding an inverse relationship between Catholic monopoly and Catholic commitment) (Stark 1992), in 150 largest US cities in 1906 (Finke \& Stark 1988), in 942 towns and cities in New York State from 1855 to 1865 (Finke et al 1996), and in 284 municipalities in Sweden (Hamberg \& Pettersson 1994). Further, just as state regulation makes for inefficient business firms, state regulation of religion also makes for inefficient religious firms and dampens the mobilization of religious consumers (Chaves \& Cann 1992).

It is well known that strict churches are strong and growing in the contemporary United States, whereas liberal ones are declining (Kelley 1972). For Iannaccone $(1992,1994)$ religious experience is a jointly produced collective good. Thus members of a church face a collective action problem. Strict churches, which often impose costly and esoteric requirements on their members, are able to solve this problem by weeding out potential free riders, since only the very committed would join the church in the face of such requirements. Finke \& Stark (1992) use this theory to account for the winners and losers in the history of the religious economy of the United States. Consistent with the notion that religious experience is a collective good, Iannaccone et al (1995) show that churches that extract more resources from their members (in the form of time and money) tend to grow in membership.

\section{Gender}

Although critics (Ferber \& Nelson 1993, Risman \& Ferree 1995) have claimed that rational choice is oblivious to gender distinctions, and therefore is unable to account for female behavior, here, too, there is disconfirming evidence 
(Friedman \& Diem 1990, 1993). Thus Brinton (1993) explains persistent gender inequalities in Japan partly as a function of parents' (mostly mothers') calculated decisions to invest more in their sons' education than in their daughters'. Due to the absence of a reliable social security system and the continued importance of a patrilineal family system, Japanese parents are financially dependent on their sons in their old age. This gives parents an interest in raising financially secure sons. By contrast, daughters will be incorporated into other families. Brinton (1989) also explains the disparity in educational attainment between Japanese men and women in rational choice terms. Japanese employers tend not to hire university-educated women because they have very few years left to work for the company before they invariably retire to get married at around age 25 (Brinton 1992). University-educated women thus represent poorer investment prospects for the company than women with high school or junior college education who leave school at an earlier age and also can be hired at lower wage rates. Given these constraints imposed by the employers, most Japanese women choose not to pursue a university education. In a study that addresses occupational specialization by gender, Cowen (1996), an economist, seeks to explain why so few women have become famous painters in history. His evidence shows women were discouraged from pursuing careers in the visual arts by the constraints of marriage and childbearing.

Supporting Hechter (1987), and later Friedman et al (1994, Hypothesis S-1), Treas (1993) demonstrates that a "collectivized" financial arrangement among married couples (joint bank accounts without separate ones for husbands and wives), which increases the financial dependence of the spouses on their marriage, is strongly associated with more stable unions. The general conclusion of Treas's study of married couples' financial organization is that principles of transaction cost economics accurately describe the choices of both husbands and wives. Treas \& Giesen's (1996) analysis of a national probability sample from the National Health and Social Life Survey shows that, while men are more likely to have extramarital affairs than women, identical considerations of opportunities, costs, and benefits underlie both men's and women's decision to engage in illicit sex.

Mackie (1996) offers an intriguing explanation for the varying fates of two institutions affecting women in less developed societies. Whereas female genital mutilation persists in Africa despite modernization, public education, and legal prohibition, female footbinding lasted for a thousand years in China but ended in a single generation. Mackie argues that each institution is a self-enforcing convention maintained by interdependent expectations on the marriage market. Footbinding in China was overturned by the establishment of associations of parents who pledged not to footbind their daughters nor let their sons marry 
footbound women. Such pledge associations have not been established in Africa, however, and female genital mutilation persists there.

\section{Organizations}

At least since Coase (1937), rational choice analyses of organizations have proliferated. Since most of the research on capitalist firms is conducted by economists, it is not reviewed here. However, some sociologists have also made contributions. Thus Petersen (1992) analyzes the earnings of 63,000 salespersons in 178 department stores and finds that those who work under outputrelated payment systems (and receive either straight commission or salary plus commission) earn considerably more than those who work under non-outputrelated payment systems (and receive straight salary alone). Workers in the former system earn more because they are individually rewarded for working harder, while those under the latter system do not because they have no incentive to work harder. (For another analysis of the capitalist firm, see Raub \& Keren 1993.)

Hedström (1994) combines rational choice with network analysis to explain the spatial diffusion of labor unions in Sweden from 1890 to 1940. Individuals' decisions to form a labor union are influenced not only by their expectations of what others will do, but also by their knowledge of what others in their immediate network have done in the past. As anticipated, both spatial properties of the network and its density turn out to be important determinants of the speed and success of labor union formation. Brüderl et al (1993) explain career mobility in a large West German company in terms of the organizational structure and hierarchies, and Greve (1994) similarly explains job mobility in Norway in terms of organizational diversity.

Haveman (1995, Haveman \& Cohen 1994) uses the characteristics of the industry and organizational ecology at the meso level to account for individual careers and job turnover at the micro level, which then aggregate to tenure distributions at the organizational level. Her work therefore exemplifies the multilevel causal structure (albeit meso-micro in this case) typical of rational choice theory. Abell $(1988,1990)$ studies industrial producer cooperatives in Tanzania, Sri Lanka, and Fiji and concludes that the key to their success lies in support organizations. While agricultural and commercial sectors have distinct capital advantages over the industrial sector in these developing nations, these established sectors have no compelling incentive to promote cooperatives. Abell \& Mahoney (1988) examine similar cooperatives in India, Peru, and Senegal and note that one of the determinants of their success in these countries is the solidarity, whether exogenously or endogenously produced, of cooperative members.

Other rational choice sociologists focus on noncapitalist firms and on unconventional organizations like urban and criminal gangs. Walder's (1986) analysis 
of Chinese factories focuses on the attainment of compliance in a communist system. Although workers in capitalist firms usually are motivated both by firm-internal sanctions and by pressure from the labor market, the latter source of incentives was largely unavailable in China at the time of Walder's study. Instead, motivation was provided by much stronger dependence and monitoring mechanisms than those typically found in capitalist firms. Workers in China depended on factory leaders for the satisfaction of a broad range of social benefits that could not be satisfied elsewhere. Dependence was further increased by workers' inability to switch jobs. (Hechter \& Kanazawa 1993 show that similar mechanisms are routinely employed in capitalist firms in Japan.) Nee (1992) accounts for the relative success of private firms over their state and collective counterparts in the transitional economy of China in terms of the former's transaction cost advantage over the latter. In contrast, Walder (1995) attributes China's rapid industrial growth under its transitional economy to the higher efficiency of public firms, especially those run by local governments, which face different financial incentives and constraints than the central government.

Two notable qualitative contributions to the literature on organizations are Gambetta's (1993) analysis of the Sicilian Mafia, and Jankowski's (1991) ethnographic study of urban street gangs in three American cities. For Gambetta, the Mafia is a firm offering private protection in a society where state protection often is unreliable. (Jankowski's gangs also offer protection for the residents of low-income neighborhoods who are not well-served by police.) Because the Mafia lacks legitimacy and cannot guarantee its products, it must first convince potential customers of their quality. Gambetta interprets seemingly bizarre aspects of the Mafia - its arcane rituals, obscure symbols, and blood ceremonies - as attempts to make credible commitments to customers and rivals alike.

\section{Crime and Deviance}

Deterrence theory has long been identified as an application of rational choice (Gibbs 1975). With Cornish \& Clarke (1986), rational choice theories of crime emerged to explain criminal behavior as a function of expected reward and punishment, weighted by the subjective probability of detection (Piliavin et al 1986). Jacobs' (1996) interviews with 40 active crack dealers show that their behavior and their interpersonal strategies are jointly determined by their desire to maximize profit from their sales and to minimize the possibility of arrest by undercover narcotics officers. The dealers, who mostly interact with anonymous clientele, employ a perceptual shorthand on unfamiliar clients; these are observational and testing techniques to detect deception on the part of the clients. Horney \& Marshall's (1992) analysis of data collected from incarcerated adult offenders of major felonies confirms that the criminals' subjective 
perception of the risk of detection is realistically updated by their own experience in the particular crime; those who commit the crime often without getting caught lower their expectation of detection while those who are caught most of the time subsequently increase their perception of risk. Recently, rational choice perspectives on crime have converged with the routine activity approach (Clarke \& Felson 1993). Both distinguish between criminality (the decision to become involved in a particular form of crime) and crime (an actual criminal event), and explain the latter in terms of opportunities - the simultaneous presence of criminal target and absence of risk of detection.

A distinctive thrust of rational choice theories of crime is their conception of criminality as a function of higher expected material returns from criminal activities relative to those from conventional pursuits. Williams (1989), Jankowski (1991), and MacLeod (1995) all provide ethnographic accounts to show that teenagers in low-income neighborhoods make deliberate decisions to pursue criminal activities because few legitimate alternative means to make as much money are available to them. Jankowski (1991, pp. 180-193) notes that, in some chronically poor neighborhoods, gang membership has become a family tradition, and many parents actively encourage their children to belong to the same gangs to which they themselves belonged when they were younger, much as parents with Ivy League educations encourage their children to attend their alma maters. Pezzin (1995) argues that economic incentives and opportunity costs exert a powerful influence on criminal career duration and desistance choice. Her analysis of the National Longitudinal Survey of Youth shows that future expected criminal earnings have a strong negative effect on the decision to terminate a criminal career among youths between the ages of 16 and 22 . Since the effect of the availability of legal income-generating activities is just as strong as that of perceived cost of punishment, Pezzin argues that the carrot may work just as efficiently as the stick in shortening the length of criminal careers.

Pampel \& Gartner (1995) provide a multilevel explanation for variations in homicide rates in 18 advanced industrial nations. Other researchers stress the need to include institutional factors in the explanations of crime. Hechter \& Kanazawa (1993) use Hechter's (1987) theory of group solidarity to explain the low crime rates in contemporary Japan. They argue that the higher dependence of the Japanese on their groups and their higher visibility within the groups increase their conformity to social norms. They reject cultural explanations of low crime rates in Japan by showing that China and South Korea, which share many cultural characteristics with Japan, have higher crime rates, and that the same mechanisms of dependence and visibility work to induce conformity among American auto workers in Japanese transplants factories. Petee et al's (1994) finding that the deterrent effects of informal sanctions are the strongest among communities characterized by higher levels of integration is also consistent 
with Hechter's (1987) theory, which predicts that compliance to norms is a multiplicative function of the dependence and the efficiency of social control.

Finally, one of the most influential modern theories of crime and deviance, Hirschi's (1969) control theory, has a strong rational choice flavor (see Hirschi 1986, 1994). This theory explains juveniles' propensity to engage in delinquency in terms of preferences ("attachment," "belief"), opportunity cost ("commitment"), and resource scarcity ("involvement"). Nagin \& Paternoster (1994), among others, provide empirical support for control theory.

\section{Comparative-Historical Sociology}

Many have claimed that the scope of rational choice theory is limited to the capitalist era, for previous social formations were much less individualistic. However, rational choice historical sociologists have accounted for variation in state autonomy and policy implementation in absolutist societies on the basis of dependence and control mechanisms. Thus Kiser (1986-1987) suggests that the most autonomous early modern monarchs had independent resources and faced the weakest monitoring (legislative and judicial) institutions. Kiser et al (1995) show that in the case of war - a policy that rulers tended to favor more than their subjects - high ruler autonomy resulted in more frequent war initiation in early modern Western Europe.

Even the most autonomous rulers must delegate authority to agents if they are to implement policies, however. Hence, agency theory ought to cast light on the causes and consequences of tax administration. For instance, when the ruler's monitoring capacity is poor, tax farming should be a more efficient means of providing state revenue than bureaucratic administration because it gives agents stronger incentives to collect taxes and surrender them to rulers (Kiser 1994). Supportive evidence is found both in early modern Prussia (Kiser \& Schneider 1994) and Imperial China (Kiser \& Tong 1992). In a similar vein, Adams (1996) explains the failure of the Dutch East Indies Company, and contrasting success of the English East Indies Company, in terms of the problems that the European owners faced in controlling their agents in Asia. The Dutch company collapsed when colonial servants saw better alternative opportunities offered by the English company, and the Dutch owners were not able from afar to stop their servants' defection.

Explaining major institutional shifts is one of the great challenges of historical sociology. Both of the popular perspectives in historical sociologystructuralism and cultural analysis - would appear to face insuperable difficulties in accounting for institutional change endogenously. One such institutional change is the subject of Friedman's (1995) recent study. Until the late nineteenth century, in all Western societies the custody of children after their parents' divorce or separation was presumptively and routinely awarded to their fathers. 
Then, between 1880 and 1920, in all of these countries presumptive custody shifted from the father to the mother. Due to rising divorce rates, these states faced the prospect of having to support a large number of divorced women on welfare. In order to avoid this expenditure, Friedman argues, they transferred the custody of children from fathers to mothers, making fathers responsible for the financial welfare of their children. Divorced fathers' child support payments also secondarily contributed to the economic welfare of their former spouses, the custodial mothers. By this means, all Western countries avoided supporting divorced women and took responsibility only for the education of children.

\section{Political Sociology}

Although collective action is an abiding concern of rational choice research on politics, much of the effort has been theoretical and therefore falls outside of the purview of this review (for a comprehensive but acerbic review, see Udèhn 1995). There are notable exceptions, however. In an impressive study, Brustein (1996) seeks to explain the rise of the Nazi party in interwar Germany. Hitler's rise is often ascribed to his party's manipulation of emotional voters susceptible to ressentiment, but Brustein argues that the popularity of the National Socialists was due to their strategic adoption of policies that appealed to the pocketbook interests of a large and socially heterogeneous part of the electorate. One of his intriguing conclusions is that Hitler had to conceal his antisemitism in order to gain popularity among blue-collar workers. Brustein's theory is strongly supported by his analysis of data on more than 42,000 Nazi members who joined the party between 1925 and 1933.

Survey data collected and analyzed by Opp et al (1995) reveal how the macro outcome of the successful protest movement in East Germany in 1989 was an aggregate result of the values, incentives, and network ties of Germans at the micro level. These individuals' decisions to participate, in turn, were influenced by macrolevel political conditions. In contrast, Shlapentokh (1995) accounts for the absence of collective protests in Russia in the face of deteriorating social and economic conditions in 1992-1994 in terms of individuals' expectations that such collective action would not be successful.

\section{Stratification and Mobility}

Human capital theory long has been the principal rational choice approach to stratification. A vast sociological literature on labor markets compares its merits to those of status attainment and structural perspectives. However, a new rational choice approach to stratification has been developed. Logan (1996b) employs a two-sided logit methodology to model employment outcomes (the matching of workers to jobs) as a function of explicitly rational choices made by workers and employers under structural constraints. The jobs that employers 
supply function as the constraints within which workers make their choices, given their preferences; the supply of workers functions as the constraint within which employers make their choices, given their preferences. Further, the preferences of the employers for certain types of workers create the constraints for the workers, and the preferences of the workers for certain types of jobs create the constraints for the employers. Logan's analysis of General Social Survey data showcases the utility of this new method.

Until 1967, secondary schools in Ireland charged their students tuition fees, and these costs were thought to be barriers to educational attainment for children from working-class families. However, when these tuition fees were eliminated by the educational reform of 1967 , access to secondary education did not become more egalitarian. Raftery \& Hout (1993) argue that, due to the high employment rate and high wages in the Irish economy in the late 1960s, the opportunity costs of continuing education (in the form of forgone wages) were high, relative to the cost of tuition fees, now eliminated. Thus, it did not make much economic sense for Irish children of working-class families to continue formal education and postpone full-time employment, even in the absence of tuition fees, and the educational reform failed to have the intended effect. Breen \& Whelan's (1993) analysis concurs with Raftery \& Hout (1993).

Walder (1992) provides a macro-meso explanation of stratification among organizations in a socialist economy, and he tests it with survey data gathered in a large Chinese industrial city. Budgetary resources of the local government and its dependence on a work organization jointly determine how much revenue the local government extracts from the organization. The level of revenue extraction by the government determines (at the meso level) the organization's abilities to provide benefits to its employees, which then aggregates (at the macro level) to inequalities among organizations. Walder's (1992) explanation of organizational stratification in China is therefore another example of the multilevel causal structure of rational choice theory.

\section{Race and Ethnic Relations}

Most of the rational choice research in this area has been theoretical, with relatively few empirical applications. Clark (1991), however, finds empirical support for Schelling's (1971) theory that slight differences in residents' preference for the racial composition of their neighborhood quickly lead to extreme segregation. Nee et al (1994) contend that the structure of ethnic and ethnically mixed economies in Los Angeles is a function of the economic opportunities and constraints that Asian immigrants face as well as of their skills and qualifications. While most Asian immigrants prefer to work outside of their ethnic enclaves to take advantage of higher pay and better working conditions, many are unable to do so because of their lack of occupational and language skills. 
One means of upward mobility available to immigrants of little occupational and language skills is entrepreneurship. Sanders \& Nee (1996) demonstrate that the self-employment status among Asian and Hispanic immigrants is strongly facilitated by human capital (foreign-earned formal education) and financial and social capital available from their family members. Those with spouses and other family members who can contribute to their business are more likely to succeed as entrepreneurs than are single immigrants.

Split labor market theory can explain how ethnic and racial antagonism arises, but it cannot account for interracial solidarity. Brown \& Boswell (1995) use Heckathorn's $(1988,1989,1990)$ theory of group-mediated social control to address the possibility of interracial solidarity or strikebreaking under split labor market conditions. Their qualitative comparative analysis of the Great Steel Strike of 1919 largely supports their predictions.

Chai's (1996) theory of ethnogenesis seeks to explain the location of ethnic boundaries in developing societies. The theory proposes a link between cooperation and altruism in small, rural communities. Then it predicts how these altruistic preferences, in conjunction with structural factors and rational behavior, generate boundaries for larger-scale ethnic collective action. The theory is applied to the creation of new ethnic groups among the Pan-Igbo in Nigeria, the Luba-Kasai in Zaire, the Pan-Malays in Malayasia, and the Muhajir in Pakistan.

Group process researchers mostly concentrate on the dynamics of dyads and small groups. Research in this tradition began with Emerson's (1962) seminal analysis of exchange relations in dyads, which was later extended to exchange networks (Cook \& Emerson 1978). Currently at least four theories compete in the field of network exchange: Bienenstock \& Bonacich's core theory (1992, 1993; Bonacich \& Bienenstock 1993, 1995); Cook \& Yamagishi's power-dependence theory (1992; Yamagishi \& Cook 1993); Friedkin's expected value theory $(1986,1992,1993)$; and Willer et al's exchange resistance theory (Markovsky et al 1988, Markovsky et al 1993, Lovaglia et al 1995, Skvoretz \& Lovaglia 1995). Since this field relies heavily on the experimental testing of key hypotheses (Skvoretz \& Willer 1993), it resembles what Collins (1994) calls "high-consensus, rapid-discovery" science.

Currently there is a debate about the determinants of dyadic cohesion among self-interested rational actors. On the one hand, Kollock (1994) argues that when the outcome of an exchange is uncertain, individuals make commitments to particular exchange partners in order to reduce uncertainty (see also Yamagishi \& Yamagishi 1994). On the other, Lawler \& Yoon's (1993, 1996) theory of relational cohesion maintains that individuals experience positive affect from successfully negotiated and completed exchanges. Then selfinterested actors develop affective commitment to particular exchange partners, even in the face of more attractive offers, in order to consume this positive affect from continued exchange with the same partner. 
Sometimes research on group processes has clear macrolevel implications. Orbell \& Dawes' $(1991,1993)$ “cognitive miser” theory explains social welfare, order, and efficiency at the macro level in terms of dyadic interactions at the micro level. Their theory argues that intending cooperators are more likely to play dyadic Prisoner's Dilemma games than intending defectors, when they have the option not to play. Then the outcomes of most completed games are mutual cooperation, whereby the players enjoy the fruit of cooperation, which aggregates to order and economic surplus at the macro level. Their laboratory experiment (Orbell \& Dawes 1993) confirms the theory's crucial hypothesis that intending cooperators are more likely to choose to play than intending defectors.

The problem of cooperation and public goods provision is usually conceived of as an $n$-person Prisoner's Dilemma game. In contrast, Diekmann's (1985, 1986, 1993) "volunteer's dilemma" game captures the problem of cooperation in situations where there is a potential diffusion of responsibility (Darley \& Latanè 1968, Latané \& Darley 1970). The public good in the volunteer's dilemma is produced by a single volunteer (with the effect of additional volunteers completely superfluous), and there is no pure dominant strategy; players are better off defecting if there is at least one cooperator, but better off cooperating if there is none. The volunteer's dilemma points to the utility of sociological rational choice theory in that the use of a strictly game-theoretic solution-a mixed Nash equilibrium strategy - leads to highly inefficient outcomes. An optimal level of cooperation requires communication and coordination among actors, which is fostered by social norms (Diekmann 1985). The experimental evidence shows that subjects do not employ strictly game-theoretic solutions (Diekmann 1986, 1993).

\section{Medical Sociology}

Whereas medicine has been an important site for the application of behavioral decision theory, rational choice is in its infancy in medical sociology. Thoits (1994), however, calls for more emphasis on human agency, and on the deliberate choices that individuals make, in the study of stress and depression. Her analysis of panel data shows that individuals are often able to solve potential problems in their lives (and thus are not affected by them), and that only those they fail to solve lead to psychological symptoms. Although Pescosolido's (1992) "social organization strategy" framework ostensibly is critical of rational choice, it is entirely consistent with the version of rational choice presented in the present essay. Her analysis of individuals seeking medical help specifically incorporates network structures and uses network ties and information gathered from past interactions as resources and social capital. (Knoke 1990 and Burt 1992 offer other examples of how network analysis can be integrated with rational choice.) 
Broadhead \& Heckathorn (1994, Broadhead et al 1995) conceive of AIDS prevention as a collective action problem. They use agency theory and Heckathorn's theory of group-mediated social control to argue that peer-driven intervention programs are more effective in combating AIDS. Extensive ethnographic data support their contention.

\section{CONCLUSION}

Sociological rational choice is an inherently multilevel enterprise. It seeks to account for social outcomes on the basis of both social context and individual action. In this respect it often differs, at least in emphasis, from other (thin) versions of rational choice theory that are employed in much economic analysis and game theory. Sociological rational choice is beginning to make empirical contributions to a broad range of substantive topics in the discipline. While applications of rational choice in subfields like politics, labor markets, formal organizations, and criminology by now are traditional, the approach has also begun to make empirical advances in areas formerly regarded as inhospitable, such as the family, gender, and religion. At the same time, a growing number of theoretically uncommitted empirical researchers are testing rational choice theories - sometimes unwittingly - in their own domains. These studies will reveal much about the scope and limits of rational choice theory. Invariably, their findings will strengthen certain versions of rational choice theory at the expense of others.

Beyond the crucial task of subjecting existing rational choice theories to empirical tests, we discern three future directions for developing sociological rational choice theory. To better explain social outcomes arising from individual action, rational choice theorists must begin to understand the origin and the nature of values that motivate human behavior (Hechter et al 1993). Valuesand the preferences derived from them-are one of two major categories of determinants of individual behavior in rational choice theory, the other being institutional constraints. Rational choice has been mute on the origin and nature of individual values. This silence has been justified under the dictum de gustibus non est disputandum. Due to the difficulty of arriving at valid and reliable measures of internal states (Hechter 1992), rational choice theorists usually impute values to actors by assumption. The typical value assumption has been wealth maximization because wealth is highly fungible. Thus actors who may hold various idiosyncratic values can be expected to pursue wealth as a means to achieve their divergent goals (Hechter 1994). Yet some research also has advanced atypical value assumptions, including uncertainty reduction (Friedman et al 1994), local status (Frank 1985), distributive justice (Jasso 1990, 1993), and regret-dissonance reduction (Chai, forthcoming). 
Even if we know what values and preferences actors hold, their decisionmaking mechanisms are contested. Hence the study of decision algorithms is a second promising field of inquiry. Subjective expected utility maximization theory, the foundation of most macroscopic rational choice theories, posits that actors are forward-looking maximizers. Based on the available information and their best estimates of what the future holds, actors assign subjective probabilities to various future states of the world and make their decisions according to these subjective probabilities. However, critics have pointed out that this forward-looking process of decision-making is cognitively too demanding for most human actors (Petersen 1994). Others have proposed alternative decision algorithms. Macy (1993) argues that individuals are backward-looking adaptive learners who adjust their decisions on the basis of the past outcomes associated with their choices, and he provides experimental evidence (Macy 1995) supporting his contention. In contrast, Heckathorn (1996) argues that individuals sometimes are sideways-looking cultural imitators whose decisions emulate those made by their neighbors who are doing well. In his view, whether actors are forward-, backward-, or sideways-looking depends on the nature of available information about the future. If genuine and accurate information is available about the future, then actors will assess the subjective probabilities of various states of the world as predicted by the subjective expected utility maximization model. If the past is the best predictor of the future, then actors will be backward-looking. If the future is best known by observing who is doing well in the present, then actors will be sideways-looking imitators.

The ultimate challenge for sociological rational choice theory is explaining the emergence of institutions. Unlike values and preferences, institutions are intersubjective and therefore more easily measurable. So far this has not led to concerted research on institutional emergence, however. Still, a handful of forays have been made. Contributions to Hechter et al (1990) begin to tackle the emergence of a small handful of institutions, and Coleman (1990) provides one framework for understanding how norms emerge among actors with specific interests and resources. Logan's (1996a,b) two-sided logit model offers a promising new way to trace the origins of institutional constraints for actors to their exchange partners' preferences. And Chai \& Hechter (1997) propose an elementary model for the emergence of the state and of social order. However, an endogenous theory of institutional emergence remains a distant goal at this time.

\section{ACKNOWLEDGMENTS}

Thanks to Mary Brinton, Sun-Ki Chai, Karen Cook, and Christine Horne for comments on an earlier draft of this review. 


\section{Literature Cited}

Abell P. 1988. Establishing Support Systems for Industrial Co-Operatives: Case Studies from the Third World. Aldershot, Engl: Avebury

Abell P. 1990. Supporting industrial cooperatives in developing countries: some Tanzanian experiences. Econ. Indust. Democracy 11:483-504

Abell P. 1991. Homo sociologicus: Do we need him/her? Sociol. Theory 9:195-98

Abell P, Mahoney N. 1988. Small-Scale Industrial Producer Co-Operatives in Developing Countries. Delhi: Oxford Univ. Press

Adams J. 1996. Principals and agents, colonialists and company men: the decay of colonial control in the Dutch East Indies. Am. Sociol. Rev. 61:12-28

Baron JN, Hannan MT. 1994. The impact of economics on contemporary sociology. $J$. Econ. Lit. 22:1111-46

Becker GS. 1974. A theory of marriage: Part II. J. Polit. Econ. 82:S11-S26

Becker GS. 1976. The Economic Approach to Human Behavior. Chicago: Univ. Chicago Press

Becker GS. 1981. A Treatise on the Family. Cambridge: Harvard Univ. Press

Becker GS. 1996. Accounting for Tastes. Cambridge: Harvard Univ. Press

Bienenstock EJ, Bonacich P. 1992. The core as a solution to exclusionary networks. Soc. Networks 14:231-44

Bienenstock EJ, Bonacich P. 1993. Gametheory models for exchange networks: experimental results. Sociol. Perspect. 36:117-35

Bonacich P, Bienenstock EJ. 1993. Assignment games, chromatic number, and exchange theory. J. Math Sociol. 17:243-59

Bonacich P, Bienenstock EJ. 1995. When rationality fails: unstable exchange networks with empty cores. Ration. Soc. 7:293-320

Breen R, Whelan CT. 1993. From ascription to achievement?: origins, education and entry to the labour force in the Republic of Ireland during the twentieth century. Acta Sociol. 36:3-17

Brewster KL. 1994. Race differences in sexual activity among adolescent women: the role of neighborhood characteristics. Am. Sociol. Rev. 59:408-24

Brewster KL, Billy JOG, Grady WR. 1993. Social context and adolescent behavior: the impact of community on the transition to sexual activity. Soc. Forces 71:713-40

Brinton MC. 1989. Gender stratification in con- temporary urban Japan. Am. Sociol. Rev. 54:549-64

Brinton MC. 1992. Christmas cakes and wedding cakes: the social organization of Japanese women's life course. In Japanese Social Organization, ed. TS Lebra, pp. 79107. Honolulu: Univ. Hawaii Press

Brinton MC. 1993. Women and the Economic Miracle: Gender and Work in Postwar Japan. Berkeley: Univ. Calif. Press

Broadhead RS, Heckathorn DD. 1994. AIDS prevention outreach among injection drug users: agency problems and new approaches. Soc. Probl. 41:473-95

Broadhead RS, Heckathorn DD, Grund J-PC, Stern LS, Anthony DL. 1995. Drug users outreach workers in combating AIDS: preliminary results of a peer-driven intervention. $J$. Drug Issues 25:531-64

Brown C, Boswell T. 1995. Strikebreaking or solidarity in the great steel strike of 1919: a split labor market, game-theoretic, and QCA analysis. Am. J. Sociol. 100:1479-519

Brüderl J, Preisendörfer P, Ziegler R. 1993. Upward mobility in organizations: the effects of hierarchy and opportunity structure. Eur. Sociol. Rev. 9:173-88

Brustein W. 1996. The Logic of Evil: The Social Origins of the Nazi Party, 1925 to 1933. New Haven: Yale Univ. Press

Burt RS. 1992. Structural Holes: The Social Structure of Competition. Cambridge, MA: Harvard Univ. Press

Chai S-K. 1996. A theory of ethnic group boundaries. Nations Nationalism 2:281-307

Chai S-K. 1997. Creating Identity from Rational Action: A General Theory of Preference and Belief Formation. Ann Arbor: Univ. Mich. Press. In press

Chai S-K, Hechter M. 1997. A theory of the state and of social order. J. Math. Soc. In press

Chaves M, Cann DE. 1992. Regulation, pluralism, and religious market structure: explaining religion's vitality. Ration. Soc. 4:27290

Clark WAV. 1991. Residential preferences and neighborhood racial segregation: a test of the Schelling segregation model. Demography 28:1-19

Clarke RV, Felson M. 1993. Routine Activity and Rational Choice. New Brunswick, NJ: Transaction

Coase RH. 1937. The nature of the firm. Economica N.S. 4:386-405 
Coleman JS. 1990. Foundations of Social Theory. Cambridge: Harvard Univ. Press

Coleman JS. 1993. The rational reconstruction of society. Am. Sociol. Rev. 58:1-15

Collins R. 1994. Why the social sciences won't become high-consensus, rapid-discovery science. Sociol. Forum 9:155-77

Cook KS, Emerson RM. 1978. Power, equity and commitment in exchange networks. Am. Sociol. Rev. 43:721-39

Cook KS, Yamagishi T. 1992. Power in exchange networks: a power-dependence formulation. Soc. Networks 14:245-66

Cornish DB, Clarke RV, eds. 1986. The Reasoning Criminal: Rational Choice Perspectives on Offending. New York: Springer-Verlag

Cowen T. 1996. Why women succeed, and fail, in the arts. J. Cult. Econ. 20:93-113

Darley JM, Latané B. 1968. Bystander intervention in emergencies: diffusion of responsibility. J. Pers. Soc. Psychol. 8:377-83

Diekmann A. 1985. Volunteer's dilemma. $J$. Confl. Resolut. 29:605-10

Diekmann A. 1986. Volunteer's dilemma: a social trap without a dominant strategy and some experimental results. In Paradoxical Effects of Social Behavior: Essays in Honor of Anatol Rapoport, ed. A Diekmann, P Mitter. Heidelberg: Physica-Verlag

Diekmann A. 1993. Cooperation in an asymmetric volunteer's dilemma game: theory and experimental evidence. Int. J. Game Theory $22: 75-85$

Emerson RM. 1962. Power-dependence relations. Am. Sociol. Rev. 27:31-41

England P, Kilbourne BS. 1990. Feminist critiques of the separative model of self: implications for rational choice theory. Ration. Soc. 2:156-71

Farkas G. 1996. Human Capital or Cultural Capital? Ethnicity and Poverty Groups in an Urban School District. New York: Aldine

Ferber MA, Nelson JA, eds. 1993. Beyond Economic Man: Feminist Theory and Economics. Chicago: Univ. Chicago Press

Ferejohn JA. 1991. Rationality and interpretation: Parliamentary elections in early Stuart England. In The Economic Approach to Politics: A Critical Reassessment of the Theory of Rational Action, ed. KR Monroe, pp. 279305. New York: HarperCollins

Finke R, Guest AM, Stark R. 1996. Mobilizing local religious markets: religious pluralism in the Empire State, 1855 to 1865. Am. Sociol. Rev. 61:203-18

Finke R, Stark R. 1988. Religious economies and sacred canopies: religions mobilization in American cities, 1906. Am. Sociol. Rev. 53:41-49

Finke R, Stark R. 1992. The Churching of America 1776-1990: Winners and Losers in Our
Religious Economy. New Brunswick, NJ: Rutgers Univ. Press

Fischhoff B. 1991. Value elicitation: Is there anything in there? Am. Psychol. 46:835-47

Frank RH. 1985. Choosing the Right Pond: Human Behavior and the Quest for Status. New York: Oxford Univ. Press

Friedkin N. 1986. A formal theory of social power. J. Math. Sociol. 12:103-26

Friedkin N. 1992. An expected value model of social power: predictions for selected exchange networks. Soc. Networks 14:213-30

Friedkin N. 1993. An expected value model of social exchange outcomes. In Advances in Group Processes, ed. EJ Lawler, B Markovsky, K Heimer, J O’Brien, 10:16393. Greenwich, CT: JAI

Friedman D. 1995. Towards a Structure of Indifference: The Social Origins of Maternal Custody. New York: Aldine de Gruyter

Friedman D, Diem C. 1990. Comments on England and Kilbourne. Ration. Soc. 2:517-21

Friedman D, Diem C. 1993. Feminism and the pro- (rational-) choice movement: rationalchoice theory, feminist critiques, and gender inequality. In Theory on Gender/Feminism on Theory, ed. P England, pp. 91-114. New York: Aldine de Gruyter

Friedman D, Hechter M. 1988. The contribution of rational choice theory to macrosociological research. Sociol. Theory 6:201-18

Friedman D, Hechter M, Kanazawa S. 1994. A theory of the value of children. Demography 31:375-401

Gambetta D. 1993. The Sicilian Mafia: The Business of Private Protection. Cambridge: Harvard Univ. Press

Gibbs JP. 1975. Crime, Punishment and Deterrence. New York: Elsevier

Goldthorpe JH. 1996. The quantitative analysis of large-scale data-sets and rational action theory: for a sociological alliance. Eur. Sociol. Rev. 12:109-26

Green DP, Shapiro I. 1994. Pathologies of Rational Choice Theory: A Critique of Applications in Political Science. New Haven: Yale Univ. Press

Greve HR. 1994. Industry diversity effects on job mobility. Acta Sociol. 37:119-39

Hagan J, MacMillan R, Wheaton B. 1996. New kid in town: social capital and the life course effects of family migration on children. $\mathrm{Am}$. Sociol. Rev. 61:368-85

Hamberg EM, Pettersson T. 1994. The religious market: denominational competition and religious participation in contemporary Sweden. J. Sci. Study Relig. 33:205-16

Haveman HA. 1995. The demographic metabolism of organizations: industry dynamics, turnover, and tenure distributions. Admin. Sci. Q. 40:586-618 
Haveman HA, Cohen L. 1994. The ecological dynamics of careers: the impact of organizational founding, dissolution, and merger on job mobility. Am. J. Sociol. 100:104-52

Hechter M. 1987. Principles of Group Solidarity. Berkeley: Univ. Calif. Press

Hechter M. 1992. Should values be written out of the social scientist's lexicon? Sociol. Theory 10:214-30

Hechter M. 1994. The role of values in rational choice theory. Ration. Soc. 6:318-33

Hechter M. 1996. Through thick and thin: How far can theory predict behaviour? Times Lit. Suppl. March 29, p. 15

Hechter M, Kanazawa S. 1993. Group solidarity and social order in Japan. J. Theor. Polit. 5:455-93

Hechter M, Nadel L, Michod RE. 1993. The Origin of Values. New York: Aldine de Gruyter

Hechter M, Opp K-D, Wippler R. 1990. Social Institutions: Their Emergence, Maintenance and Effects. New York: Aldine de Gruyter

Heckathorn DD. 1988. Collective sanctions and the creation of prisoner's dilemma norms. Am. J. Sociol. 94:535-62

Heckathorn DD. 1989. Collective action and the second-order free-rider problem. Ration. Soc. $1: 78-100$

Heckathorn DD. 1990. Collective sanctions and compliance norms: a formal theory of groupmediated social control. Am. Sociol. Rev. 55:366-84

Heckathorn DD. 1996. The dynamics and dilemmas of collective action. Am. Sociol. Rev. 61:250-77

Hedström P. 1994. Contagious collectivities: on the spatial diffusion of Swedish trade unions, 1890-1940. Am. J. Sociol. 99:1157-79

Hirschi T. 1969. Causes of Delinquency. Berkeley: Univ. Calif. Press

Hirschi T. 1986. On the compatibility of rational choice and social control theories of crime. See Cornish \& Clarke 1986, pp.105-18

Hirschi T. 1994. Preface to the Japanese Edition. Causes of Delinquency. Tokyo: Bunka Shobo

Hoem JM. 1991. To marry, just in case...: the Swedish widow's-pension reform and the peak in marriages in December 1989. Acta Sociol. 34:127-35

Hoem JM. 1993. Public policy as the fuel of fertility: effects of a policy reform on the pace of childbearing in Sweden in the 1980s. Acta Sociol. 36:19-31

Horney J, Marshall IH. 1992. Risk perceptions among serious offenders: the role of crime and punishment. Criminology 30:575-94

Iannaccone LR. 1991. The consequences of religious market structure: Adam Smith and the economics of religion. Ration. Soc. 3:156-77
Iannaccone LR. 1992. Sacrifice and stigma: reducing free-riding in cults, communes, and other collectivities. J. Polit. Econ. 100:27191

Iannaccone LR. 1994. Why strict churches are strong. Am. J. Sociol. 99:1180-211

Iannaccone LR, Olson DVA, Stark R. 1995. Religious resources and church growth. Soc. Forces 74:705-31

Jacobs BA. 1996. Crack dealers and restrictive deterrence: identifying narcs. Criminology 34:409-31

Jankowski MS. 1991. Islands in the Street: Gangs and American Urban Society. Berkeley: Univ. Calif. Press

Jasso G. 1988. Whom shall we welcome?: elite judgments of the criteria for the selection of immigrants. Am. Sociol. Rev. 53:919-32

Jasso G. 1990. Methods for the theoretical and empirical analysis of comparison processes. Sociological Methodology 1990, ed. CC Clogg. Washington, DC: Am. Sociol. Assoc.

Jasso G. 1993. Choice and emotion in comparison theory. Ration. Soc. 5:231-74

Jasso G, Rosenzweig MR. 1990. The New Chosen People: Immgrants in the United States. New York: Russell Sage Found.

Kelley D. 1972. Why Conservative Churches are Growing. New York: Harper \& Row

Kiser E. 1986-1987. The formation of state policy in western European absolutisms: a comparison of England and France. Polit. Soc. 15:259-96

Kiser E. 1994. Markets and hierarchies in early modern tax systems: a principal-agent analysis. Polit. Soc. 22:284-315

Kiser E, Drass KA, Brustein W. 1995. Ruler autonomy and war in early modern western Europe. Int. Stud. Q. 39:109-38

Kiser E, Schneider J. 1994. Bureaucracy and efficiency: an analysis of taxation in early modern Prussia. Am. Sociol. Rev. 59:187-204

Kiser E, Tong X. 1992. Determinants of the amount and type of corruption in state fiscal bureaucracies: an analysis of taxation in early modern Prussia. Comp. Polit. Stud. 25:30031

Knoke D. 1990. Political Networks: The Structural Perspective. Cambridge: Cambridge Univ. Press

Kollock P. 1994. The emergence of exchange structures: an experimental study of uncertainty, commitment and trust. Am. J. Sociol. 100:315-45

Latané B, Darley JM. 1970. The Unresponsive Bystander: Why Doesn't He Help? New York: Appleton-Century-Crofts

Lawler EJ, Yoon J. 1993. Power and the emergence of commitment behavior in negotiated exchange. Am. Sociol. Rev. 58:465-81 
Lawler EJ, Yoon J. 1996. Commitment in exchange relations: test of a theory of relational cohesion. Am. Sociol. Rev. 61:89-108

Lee BA, Oropesa RS, Kanan JW. 1994. Neighborhood context and residential mobility. Demography 31:249-70

Lloyd KM, South SJ. 1996. Contextual influences on young men's transition to first marriage. Soc. Forces 74:1097-1119

Logan JA. 1996a. Rational choice and the TSL model of occupational opportunity. Ration. Soc. 8:207-30

Logan JA. 1996b. Opportunity and choice in socially structured labor markets. Am. J. Sociol. 102:114-60

Lovaglia MJ, Skvoretz J, Willer D, Markovsky B. 1995. Negotiated exchanges in social networks. Soc. Forces 74:123-55

Mackie G. 1996. Ending footbinding and infibulation: a convention account. Am. Sociol. Rev. 61:999-1017

MacLeod J. 1995. Ain't No Makin' It: Aspirations and Attainment in a Low-Income Neighborhood. Boulder, CO: Westview

Macy MW. 1993. Social learning and the structure of collective action. In Advances in Group Processes, ed. EJ Lawler, B Markovsky, K Heimer, J O'Brien, pp. 1-35. Greenwich, CT: JAI

Macy MW. 1995. PAVLOV and the evolution of cooperation: an experimental test. Soc. Psychol. Q. 58:74-87

Markovsky B, Skvoretz J, Willer D, Lovaglia MJ, Erger J. 1993. The seeds of weak power: an extension of network exchange theory. Am. Sociol. Rev. 58:197-209

Markovsky B, Willer D, Patton T. 1988. Power relations in exchange networks. Am. Sociol. Rev. 53:220-36

Moen P, Wethington E. 1992. The concept of family adaptive strategies. Annu. Rev. Sociol. 18:233-51

Nagin DS, Paternoster R. 1994. Personal capital and social control: the deterrence implications of a theory of individual differences in criminal offending. Criminology 32:581-606

Nee V. 1992. Organizational dynamics of market transition: hybrid forms, property rights, and mixed economy in China. Admin. Sci. $Q$. 37:1-27

Nee V, Sanders JM, Sernau S. 1994. Job transitions in an immigrant metropolis: ethnic boundaries and the mixed economy. Am. Sociol. Rev. 59:849-72

Opp K-D, Voss P, Gern C. 1995. Origins of a Spontaneous Revolution. Ann Arbor: Univ. Mich. Press

Orbell J, Dawes RM. 1991. A cognitive miser theory of cooperators' advantage. Am. Polit. Sci. Rev. 85:515-28

Orbell JM, Dawes RM. 1993. Social welfare, cooperators' advantage, and the option of not playing the game. Am. Sociol. Rev. 58:787800

Pampel FC, Gartner R. 1995. Age structure, socio-political institutions, and national homicide rates. Eur. Sociol. Rev. 11:243-60

Pescosolido BA. 1992. Beyond rational choice: the social dynamics of how people seek help. Am. J. Sociol. 97:1096-1138

Petee TA, Milner TF, Welch MR. 1994. Levels of social integration in group contexts and the effects of informal sanction threat on deviance. Criminology 32:85-106

Petersen T. 1992. Payment systems and the structure of inequality: conceptual issues and an analysis of salespersons in department stores. Am. J. Sociol. 98:67-104

Petersen T. 1994. On the promise of gametheory in sociology. Contemp. Sociol. 23:498-502

Pezzin LE. 1995. Earnings prospects, matching effects, and the decision to terminate a criminal career. J. Quant. Criminol. 11:29-50

Piliavin I, Thornton C, Gartner R, Matsueda RL. 1986. Crime, deterrence, and rational choice. Am. Sociol. Rev. 51:101-19

Raftery AE, Hout M. 1993. Maximally maintained inequality: expansion, reform, and opportunity in Irish education, 1921-1975. Sociol. Educ. 66:41-62

Raub W, Keren G. 1993. Hostages as a commitment device. J. Econ. Behav. Organ. 21:4367

Risman BJ, Ferree MM. 1995. Making gender visible: comment on Coleman. Am. Sociol. Rev. 60:775-82

Sanders JM, Nee V. 1996. Immigrant selfemployment: the family as social capital and the value of human capital. Am. Sociol. Rev. 61:231-49

Schelling T. 1971. Dynamic models of segregation. J. Math Sociol. 1:143-86

Sen A. 1983. Economics and the family. Asian Dev. Rev. 1(2):14-26

Shlapentokh V. 1995. Russian patience: a reasonable behavior and a social strategy. Eur. $J$. Sociol. 36:247-80

Skvoretz J, Lovaglia MJ. 1995. Who exchanges with whom: structural determinants of exchange frequency in negotiated exchange networks. Soc. Psychol. O. 58:163-77

Skvoretz J, Willer D. 1993. Exclusion and power: a test of four theories of power in exchange networks. Am. Sociol. Rev. 58:80118

Smith HL. 1989. Integrating theory and research on the institutional determinants of fertility. Demography 26:171-84

South SJ, Lloyd KM. 1995. Spousal alternatives and marital dissolution. Am. Sociol. Rev. 60:21-35 
214 HECHTER \& KANAZAWA

Stark R. 1992. Do Catholic societies really exist? Ration. Soc. 4:261-71

Stark R, Bainbridge WS. 1985. The Future of Religion: Secularization, Revival, and Cult Formation. Berkeley: Univ. Calif. Press

Stark R, Bainbridge WS. 1987. A Theory of Religion. New York: Peter Lang

Stark R, Iannaccone LR, Finke R. 1996. Religion, science, and rationality. Am. Econ. Rev. 86(2):433-37

Thoits PA. 1994. Stressors and problemsolving: the individual as psychological activist. J. Health Soc. Behav. 35:143-59

Treas J. 1993. Money in the bank: transaction costs and the economic organization of marriage. Am. Sociol. Rev. 58:723-34

Treas J, Giesen D. 1996. Sex, gender, and rational choice: determinants of infidelity among married and cohabiting couples. Presented at Annu. Meet. Am. Sociol. Assoc., Aug. 1620, New York

Udéhn L. 1995. The Limits of Public Choice. London: Routledge

Walder AG. 1986. Communist Neo-Traditionalism. Berkeley: Univ. Calif. Press

Walder AG. 1992. Property rights and stratification in socialist redistributive economies.
Am. Sociol. Rev. 57:524-39

Walder AG. 1995. Local governments as industrial firms: an organizational analysis of China's transitional economy. Am. J. Sociol. 101:263-301

Warner RS. 1993. Work in progress toward a new paradigm for the sociological study of religion in the United States. Am. J. Sociol. 98:1044-93

Williams T. 1989. The Cocaine Kids: The Inside Story of a Teenage Drug Ring. Reading, MA: Addison-Wesley

Wu Z. 1996. Childbearing in cohabitational relationships. J. Marriage Fam. 58:281-92

Yamagishi T, Cook KS. 1993. Generalized exchange and social dilemmas. Soc. Psychol. $Q$. $56: 235-48$

Yamagishi T, Yamagishi M. 1994. Trust and commitment in the United States and Japan. Motiv. Emot. 18:129-66

Yamaguchi K, Ferguson LR. 1995. The stopping and spacing of childbirths and their birth-history predictors: rational-choice theory and event-history analysis. Am. Sociol. Rev. 60:272-98

Young LA. 1997. The Rational Choice Theory of Religion. New York: Routledge 